講義

\title{
シーケンスの自動制 御
}

森

政

弘 $* *$

\section{1.わが国の工業とシーケンス制御の必要性}

日本人は手先が器用である。 また日本には物的資源が

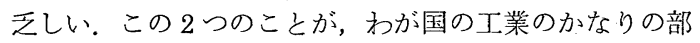
分に種々の特殊性を与兄ている。これは先進諸国からの 輸入になる大規模な工業よりも，中小企業においていち じるしい，㵶維工業もこの例外ではない，このうち自動 化に直接関係の深い特殊性としては，（1）バッチプロ セスが非常に多いこと，（2）多種少量生産であること， （3）熟練工の名人芸に依存している個所が多いこと, などがまずあげられよう。そしてこれらはいずれる，西 きらかに自動化を実行しにくくする要因である。できる ことなら,この種の要因は極力取除き, バッチプロセ スは連続プロセスに変更し, 製品の種類は極力切りつめ 熟練工を不要とする生産方法を採用したうえで, 自動化 を考觉るのが一応合理的な行き方であることはだれしも となえるところである。

しかし現実の問題としては簡単にはこれらの要因を除 去することはできない，たとえば，プロセスの中には技 術的に連続化困難なものも多く，また多種少量生産の形 態をくずすことができぬ(高級毛織物整理工業のような) 場合には，連続プロセスにかけらるだけの同一品種の口 ット量がないこともある。また昨今の激烈な新製品競争 に対処してゆくためには，転用融通が容易なバッチプ 口セスの方がむしろ好をれるという傾向さえ生じてきて いる。ゆえにまずわが国からバッチプロセスを全部追 放することは不可能と考光られる。ささらに日本人は（日 本人に限ったことはなかららが）生活に扔いての好みの 㵶細さ, ぜいたくさ, 古来の根強い伝統, 社会機構, 習 慣などが間接的に多種少量生産形態の工業をささえ，名 人芸のできる熟練工の存在理由を高めていると見ること もできる，たとえばネクタイ工業などは多種少量生産で なければ成立しないるのの典型であろう。また風合のよ うな科学的検出の困難な，官能検査に頼らざるをえない

品質の良否が，その商品価値を大幅に左右しているので ある。したがってこの種の工業では名人芸のできる熟練 工が依然として必要なのである。

このような実情だからわが国の工業の特殊性は，一朝 一夕に自動化がしやすい形態に変化することはまずない と覚语せねばならないだろう。をた一面，むしろこの特 殊性を保存することこそ, わが国の工業の国際的な地位 を守ることにならう。ささら逆に連続プロセスで手がけ られるものだけを少品種多量生産の形で生産し, 製品の 品質についての㵶細な（むしろ芸術的な）検定を否定す ることにでもなれば，それこそ極端ではあるが，全国同 一色, 同一形の服を着るという, 殺風景な戦时の畒に帰 ってしまうことになる。

だがー方このような事情にありながら，自動化の必 要性は最近ではとくに増大してきている。 その原因は多 々あろうが，1つには貿易の自由化開始によりわが国の 工業が国際競争の荒波にさらされることになったことが あげられる。また，わが国人口の年令別分布が年少者の 方が少ないという逆三角形を呈してきているため, 近き 将来にはかならず, 若い労働人口は減少し, 老いた非生 産的人口が增加するという事態が到来する。それに加光 て最近めざましく向上した生活程度を，その近き将来に おいても維持ないしは発展させるためには, 労働人口 1 人あたりの生産量を何倍にも增加する必要があり，その ためには自動化を着々実行してゆかね柿ならなくなっ たということも他の1つの理由としてあげることができ る.

こう考えてくると, 以上の自動化のしにくい要因を含 むわが国工業の特殊事情をある程度は肯定して，ぜがひ でもその自動化を真剣に考皇ねばならず，いたずらに先

* 最終需要家である一般家庭よりも, 主として問屋 のような中間業者によってての種の品質がきびし く判定されているのが実情である

* Sequence Control. 
進諸外国の自動制御技術に迫従することだけで突心すべ きではなく、わが国の工業に適合した形態の自動制御を 独自で開拓せねばならないと結論できる。

この論拠より,われわれはバッチプロセスの自動化 をまた連続プロセスについてもその運転人員のいっそ らの減少を主目的とした自動化を研究することが急務と いえる. シーケンス制御はこの要求に対して, ある角度 から答えることのできるものである。

\section{2. シーケンス制御とは}

バッチプロセスの自動化に際しては, 連続プロセス の自動制御で偉力を発揮している流量, 压力, 温度, $\mathrm{pH}$ などの值を制御する，いわゆるプロセス調節計によるフ イードバック制御だけでは，自動化の効果はあまり上 がらない。とくに人員の節減に対しては調節計によるプ ロセス制御は無力に近い. バッチプロセスを運転人員 を削減することを主目的として自動化するためには，バ ッチ式の特質である各バッチごとの原料の仕込み，製品 の排出, 各種の弁の時間やプロセス状況に応じての切換 え,などの作業順序進行を自動化することがすず必要で ある.このような各バッチごとの作業順序を自動的に進 行させる制御をジーケンス自動制御という。これなしに はバッチプロセスの運転人員を節減して自動化の実を あげることはできない。また連続プロセスに和いてす， 定常運転中の圧力, 温度などのプロセス諸量の調節動作. だけの調節計による自動化だけでなく，その起動や停止 に関係した諸動作までも自動化しなければ, 完全自動化 による合理化の実は上げにくいと思う。そのためには連 続プロセスにもシーケンス制御を採用するのがよい。 昭和 36 年度に審議された自動制御用語 J I S 原案では, シーケンス制御の用語の意味はつぎのようになってい る.

シーケンス制御：あらかじめ定められた順序にしたが つて制御の各段階を逐次進めていく制御。

〔備考〕シーケンス制御では, つぎの段階で行ならべ き制御動作があらかじめ定められていて, 前段 階における制御動作を完了したのち, あるいは 動作後一定時間経過したのちにつぎの動作に移 行する場合や，制御結果に応じてつぎに行なう べき動作を選定して，つぎの段階に移行する場 合などが組合わされることが多い。

日本規格協会一必要の方は問合わせられたい
実はこのような自動制御は第 2 次大戦前からすでに化 学プロセス以外では多少は実施されていた。 とくに強電 関係, すなわち発変電所の起動停止や, 各種压延機, 巻 上機などの大形電動機が使用されている個所では, その 起動, 逆転, 停止などに関連して昭和のはじめごろから 行なわれていた。このため電気分野ではあまりにも常識

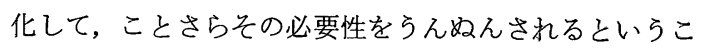
ともなしに進んできたよらである。そこへ戦後サーボ機 構やプロセス制御などのフィードバック制御方式が登 場し,フィードバックが極度に重要視され, “フィード バックがなければ制御とはいえない”,とまでいわれる ようになった。この風潮に押されて、シーケンス制御は フィードバックがないとの理由で, 自動包装機の類の 自動機械とともに自動制御の研究の対象としてとり上げ られなくなってしまった。柴粎この事実は本当のところは, シーケンス制御を無視し忘却してもよいということでは なく，それは，自動制御関係者は常識として当然心得て いなければなら基礎的事項であることを物語っていた のであった．乙かしこの風潮が強すぎたのか，それとも 自動制御は教えるべき内容が多すぎるためからか，たび 重なる各団体主催の自動制御講習会でも，また大学の制 御工学の講義に扎いても, シーケンス制御はほとんど講 義されずに今日にいたったのである.

このため, 戦後に和いてはじめて自動化技術がはいり 込んだプロセス工業畑では，調節計によるプロセス制御 という歴史の新しい自動制御に関しては, 関心も深く, 知識も豊富で, 実施も広範囲大規模に和よんでいるのだ が，この歴史の古いシーケンス制御に関しては，その言 葉さえも耳にされたことがないといら状沉をるねいたの である。

ところがここ数年来の筆者の経験によると，このプロ セス工業（繊維工業も含めて）をはじめとして，いるま でシーケンス制御が浸透していなかった分野にこれを害 施してみたところ，意外にも大きな収獲が上がったこと

**** 後述のように, シーケンス制後にフィードバッ クがないといのは愦りである。とくに現在の 進步したシーケンス制御では，いたるとこるに フイードバックを採用し，磪実安全を期してい る

粎忘だし，工場現場では電気関係ではもちろん， 機械関係でも，トランスファ マシンや工作機械 とくにその数徝制御ではシーケンス制御が採用 されある程度身近なものとなってきた 
が多かった．これは考えてみれば当然の話であって，わ れわれの日常生活の諸動作をはじめ, “各工程でンーケン ス制御に無関係なものはまずほとんどないからであろ う.

シーケンス制御の今日の状況は, 電気畑では古くから 行なわれてきているその技術が，分野の異なったプロセ ス工業に和いて，新しい形態で再興されつつあると見る ことができよう。

自動化のためにぎりぎりのところどこまで金がかけ うるか, あるいはどこまでの価格の自動制御装置を購入 してもよいか，という問に対する答は，おおざっぱなが ら次式で表わすことができると筆者は考えている。

\section{3. シーケンス制御は採算がとれるか}

もあった．第 3 項の自動化採用による損失というものも 忘れてはならない項で西る。

自動制御の方式や装置が, 学者や研究者の手をはなれ て実際の営利工場の現場へ適用されようといらときには （1）式で規定されたきびしい関簡を等を通過せねばならな い。このことは，軍事目的のような採算を度外視した場 合はいざ知らず，党利を目的とした一般の工業の場合に はすべていえることである，そして（1）式右辺第 2 項 の利益は, 計画段階に执いては算定困難な要素が多いた め, 採算の面で安全確実を期する場合には，この項を無 視して自動化の利益というものを第 1 項の人の節減だけ とみなして計画することが多く、いっそうのきびしさが 加わるわけである。しかし, 昨今の自動制御界の焦点 となっている最適制御，適応制御，計算機制御などの高

人員の節減による利益

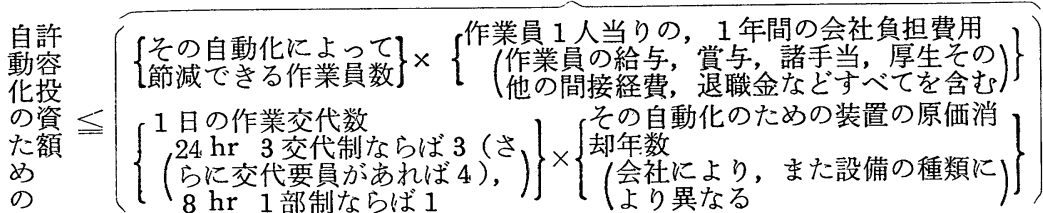

その他の利益

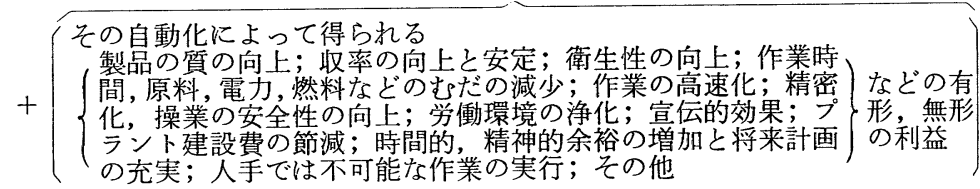

損 失

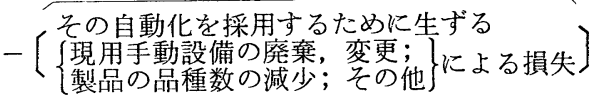

この式で右辺の第 1 項は，自動化によって得られる人 員の節減による利益であって, 自動化実施前の計画段階 において，かなりの程度定量的な算定ができるものであ る.筆者の調査によれば，この項中の，作業員 1 人当り の 1 年間の会社負担費用は，その作業員の程度にもよる が，だいたい最低 60 万程度から最高 200 万円ぐらい のものである．1日の作業交代数はもちろん最低 1 で最 高 3 （さらに緊急交代要員が置いてある場合は4）であ る. 原価消却年数はだいたいにおいて新進気鋭の工場ほ ど短く，1年といら場合さえある．また設備にもよるが 長い注らでは法定の消却年数を採用しているところもあ る. 上式の第 2 項は計画段階での算定を困難にする要素 を多分に含んで打り，自動化の実施後ある期間を経て， 運転が定常状態に落着いてからはじめてあらわれてくる 利益である、筆者の経験ではこの利益は，ほとんど零の 場合もあったし，をた予期せぬ大きなものとなったこと
級な制御方式は，（1）式中の 右辺第 1 項の人員削隇による 利益よりも，第 2 項の利益の ほうをねらったもののように 受けとれる。したがってこれ らの制御では“採算がとれる か?”といら問に対しこの

（1）式をと就して明確に答 えにくいわけでこの点がこれ らの制御方式の実用化を困難 にしている原因の一つではな からうか。

筆者はここ数年間，わが国 のプロセス工業の自動化を，とくに（1）式を満足して 採算がとれるといら点から実際的に研究した。 その結果 シーケンス制御といらものが，わが国の工業に対しては (少なくとも現段階では)，上記の高級な制御よりも実際 的に貢献することができるという自信を持ち，また事実 採算が十分とれている実施例も大小合わせて 10 例以上 経験することができた，幸なことにシーケンス制御は， それによる利益があらかじめ算定しやすい人員の節減を 直接の目的としたるのである.

※粐啸筆者の経験では, 自動化の計画段階に扣いて, 現在の各種制御要素, 装置, 付属装置の価格や 工事費などを（1）式左辺に代入した場合，そ の不等号が成立するという確信を得るととがで きを場合はそれほど多くはなく（1）式が成立 せぬか，せいぜい等号がゃっと成立するという 場合の方が多かった 
篗星が訣画あるいは实施したシーケンス制御のうち， 代表的なるの 4 例についてとの規模, 運転人員数を表示 すると第1表のようになる。

このうちB工場以外は, ぞれ子運転人員数は半分以下 に節減できている，とくに A工場の蒸気処理工程では $1 / 3$ に減少している。 またD工場とC工場との場合は, 工場新設に際し，おりからの求人難に対して偉力を発揮 したのであった，B工場の染色工程では，弁の開閉だけ を行ならシーケンス制御と, 温度と $\mathrm{pH}$ の調節計による 制御だけでは自動化の実は上がらず，反物の染色そうへ のかけはずし作業，その他が手作業のままで残っている ため，ほとんど人員節減の効果は上がっていないので

（第1 表）シーケンス制御による人員節減の実績

\begin{tabular}{|c|c|c|c|c|c|}
\hline \multirow{2}{*}{ 工場 } & \multirow{2}{*}{ I } & \multirow{2}{*}{ 継電器数 } & \multirow{2}{*}{ 弁 数 } & \multicolumn{2}{|c|}{ 運転人員数 } \\
\hline & & & & \begin{tabular}{|l|} 
自動化なし \\
の場合
\end{tabular} & $\begin{array}{l}\text { 自動化した } \\
\text { 現在 }\end{array}$ \\
\hline A & 蒸気处理 & 13 & 4 & 3 & 1 \\
\hline B & 染 & $37 \times 30 *$ & $4 \times 30 *$ & 12 & 10 \\
\hline $\mathrm{C}$ & 結 & 約 1800 & 約 700 & $\begin{array}{c}\text { 約 } 40 \\
\text { (推测值) }\end{array}$ & 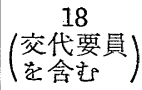 \\
\hline $\mathrm{D}$ & 醗 & 約 2500 & 約 1000 & 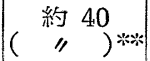 & 20 \\
\hline
\end{tabular}

*30台分を意味する

** 既存の工程を自動化したのではなく，ほじめから シーケンス制卸を適用したため, 自動化なしの場 合の人数ははっきりをは出ない

ある，B工場以外の例でも，自動化した現在の運転人員 が零（完全自動）になっていないのは，現在の技術では とても自動化できぬ，人間沈よらねばならぬ作業が残 っているか，あるい性それ以上の自動化を実施したので

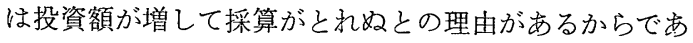
る.

シーケンス制御の効果は人員の節減以外〔上式右辺第 2項】にもある. 計画の段階では予期しなかったことだ がD工場和よびC工場の例では試運転（このときには人 員は逆にたくさん必要である）のときからすでに収率が 目に見えて安定した，またA工場の例では作業時間が正 しく一定に落着き，乙かるそれが短かくなったため1日 のバッチ回数が上がった。 B工場の場合は人員の節減こ そできなかったが，染色時間が安定短縮でき，1日3回 しか染色できなかったのが 4 回できるようになり，汇゙ 25\%の生産能率向上ができた。 また間接的に蒸気量の節 約も記録計上に現われるようになった。ささらにすべての 例についていえることだが,弁の誤操作は皆無となった。
故障はD工場の場合は保守がゆきとどいているためかま だ一度も起っていない，B工場の場合実施後 4年になる が温度検出端の絶縁不良が $4 \sim 5$ 回起っている程度であ る.A工場では弁座の材質に問題が生じ弁を交換したこ とがあった。

いうまでもなく，この 4 例とも上式を満足して採算が とれているものである，B工場の例を除いて経済的にも 成功したといってよいと思っている，以上簡単ではある が，参考までに数例の結果を披露した次第である.

\section{4. シーケンス制御の実例}

上述のようにシーケンス制御の歷史は古いものではあ るが，以下に二，三の実例をあげてこれまでシーケンス 制御になじみの薄かった方々のために，シーケンス制御 の概念をつかんでいただくことにしよう。

4.1 シーケンス制御の方式

現在のところシーケンス制御にはつぎの 3 方式があ る.

（1）カム式シーケンス制御装置を使ら方式

(2) 継電器式シーケンス制御装置を使ら方式

（3）沉用形シーケンス制御装置を使う方式

このらち（1）のカム式は, 小形電動機により駆動さ れるカムと、リミットスイッチとを組合わせることに より作業工程の時間的配分を規定するもので，もっとも 簡単な方式である. 工作機械や各種加工機械の単純なシ ーケンス制御や高級家庭電器の制御などに使われてい る.機構が簡単で安価だが，(1)すべてが時間だけで 規定されてしまう，（2）前段階の制御結果に応じてつ ぎの段階を選択するような動作はできない，（3）ある 段階まで進行したシーケンスを一部むとへもどして, 途 中からもら一度くり返したいよらな要求には応じられな いなどの欠点がある。

（2）の継電器式は現在もっとも標準的なもので, 柔 軟性に富み，小規模なるのからきわめて大規模な制御に いたるまで，一応シーケンス制御に要求される条件はす べて満足させらるものである．今日の技術の現状から見 て，この方式がもっとも実用的かつ信頼性が高いと考兄 られる、筆者がこれ亲で各方面で実施してきたシーケン ス制御はすべてこれに属する。

（3）の方式は現在ほんの試験, 試作段階のすのでし かなく、したがって実用の経験や古い歴史や伝統がある わけではない，理諭的，実験室的にはこの方式はもっと むすぐれた方式といいらるが，いますぐ工場現場での実 用問題となると $100 \%$ の責任を持って推しようすること 
は筆者はさしひかえる。しかし将来いつかはこの方式か゚ 大活躍するときがくると思う。これは電子計算機による シーケンス制御とも密接な関係がある重大問題だが，こ こでは説明は省略することにしたい，〈わしくは交献 2)，3），4）を参照されたい。以下もっぱら（2）の 継電器式シーケンス制御について解説を進める.

\section{2 継電器回路図}

継電器式シーケンス制御を理解していただくための前 提として, 標準的な継電器回路図の書き方を簡単に説明 しておこう。

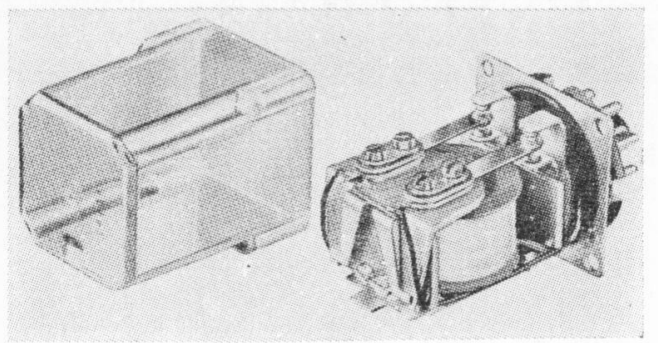

（a） 34, 号継電器（富士通信機）

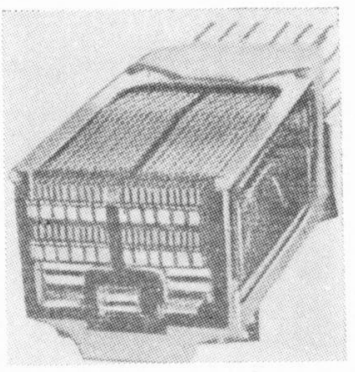

（b）ワイヤ スプリング継電器（日本電気）

（第1図）継霍器の例

第 1 図はシーケンス制御によく使う継電器の例である が, 継電器とは要するに, 電磁石のコイルへの電流をオ ン オフすることによって(一般にそのコイルとは絶縁さ れた）電気接点を開閉する要素のことをいら。したがっ て継電器の実物では, コイルと接点とは一体になってい るのだが，それを炎のまま体として図示すると配線図 が非常にさくそうするので，コイルと接点とは別々に離 して書くのが原則となっている。（この点が機械製図と は大いに異なっている)

配線図の表示方法はJIS C 0301 にも規定してあるし， またわが国では今日なお JIC (Joint Industry Conference）のものが広く使われているが，いずれも上記 の原則に立脚している. 以下に簡単にこれについて述べ よう.

（a）継電器のコイルと接点とは，実際の幾何学的位 置とは無関係に切り䛕して書く. （b）継電器のコイルは円で表わし，その中に継電器 の記号あるいは番号を記入する。

（c）接点は第 2 表の記号で表わす.

（d）回路は 2 本の電源基線を両側に引き，その間に コイルや接点などを横にならべて書き込む。

（e）左側の電源基線に沿って, 横（配）線の番地を 表示する。

（f）右側の電源基線に沿って, 継電器コイルのある 横線の位置に, その継電器の接点の所在する番地を記入 する。つまり接点の分布を示す。

（g）（f）の場合，必要に応じてはブレーク接点（常 時，つまりコイルに電流が流れないとき，閉の接点）の 所在番地を示す数字の下にはアンダ ラインを引く.

（h）配線図は，原則として動作していない状態を表 わす。たとえば，継電器接点はそのコイルに電流が流れ ていない場合の有様を，押ボタンスイッチなどは手で

（第 2 表 a ）配線図用シンボルの抜すい

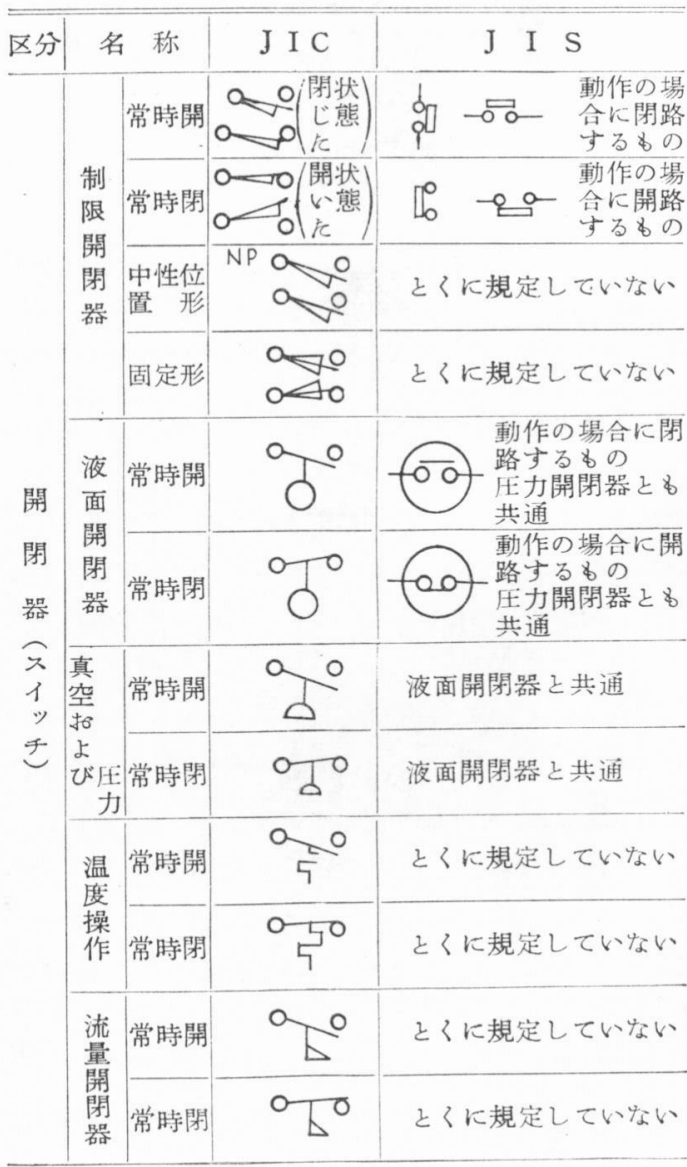

J I S 日本工業規格

J I C アメリカ産業連絡会議規格

（注）本交はJ I CKよっている 
押していない状態を表示する。

これらは，第 2 表，第 3 表を参照するとすぐ理解され よ5.

（第 2 表 b)

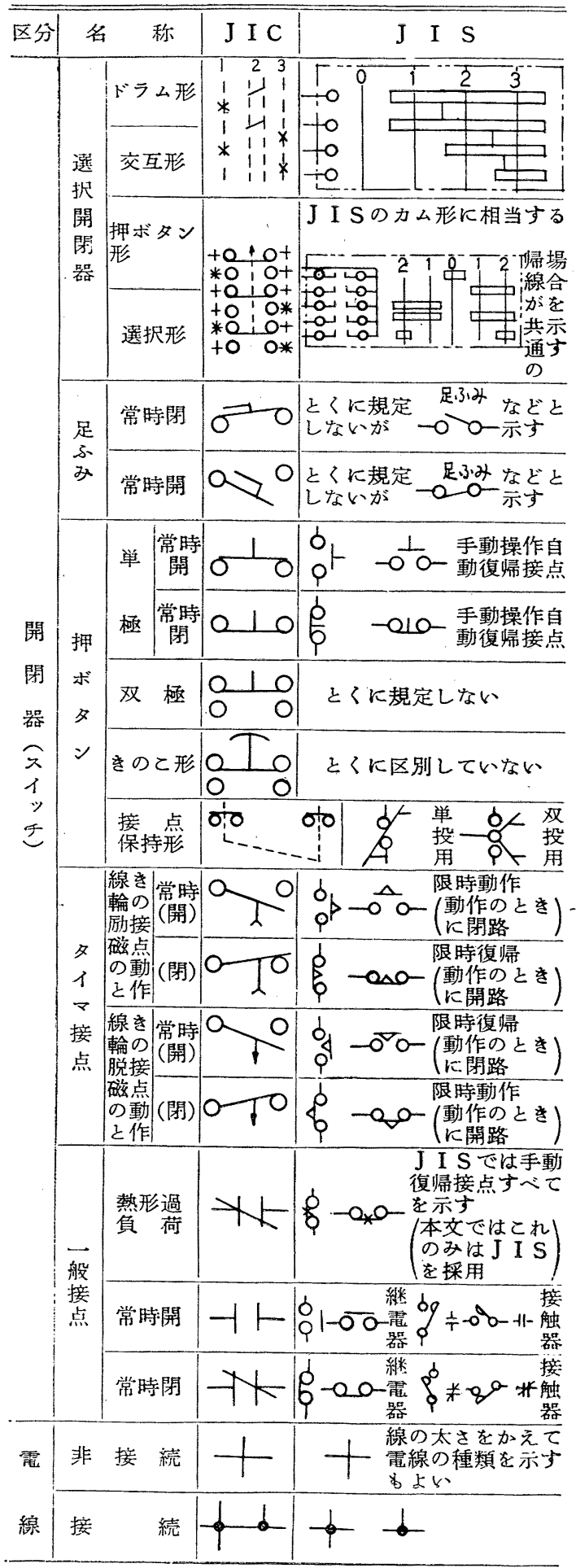

以上の予備知識をむとに，以下にシーケンス制御の簡 単な例を2，3あげよう。

4.3 気体により処理を行なうパッチプロセスのシ一 ケンス制御

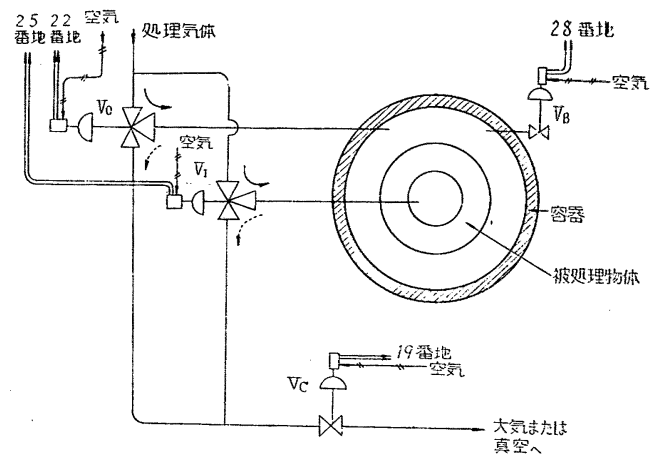

（第 2 図）バッチプロセスでの気体によ当处星

（第 2 表 c)

\begin{tabular}{|c|c|c|c|}
\hline 分 & 名 称 & $\mathrm{J}$ I C & $\mathrm{J}$ I S \\
\hline \multirow{3}{*}{$\begin{array}{l}\text { 䡢 } \\
ב \\
1 \\
\text { U }\end{array}$} & $\begin{array}{lll}\text { 継 } & \text { 電 } & \text { 器 } \\
\text { タ } & イ & マ \\
\text { な } & & \text { ぞ }\end{array}$ & & 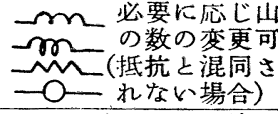 \\
\hline & 電磁弁 & & 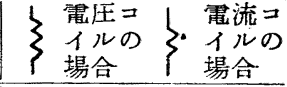 \\
\hline & $\begin{array}{l}\text { 制 御 } \\
\text { 変圧器 }\end{array}$ & 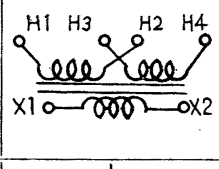 & 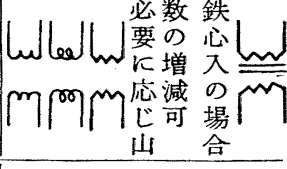 \\
\hline \multirow{2}{*}{$\begin{array}{l}\text { 整 } \\
\text { 流 } \\
\text { 器 }\end{array}$} & 半 波 & & $\begin{array}{c}\rightarrow \text { 矢印は直流の通 } \\
\text { る方向を示す。 }\end{array}$ \\
\hline & 全 波 & & \\
\hline \multirow{3}{*}{ 動 } & $\begin{array}{l}\text { 交流用 } \\
(3 \text { 相) }\end{array}$ & & 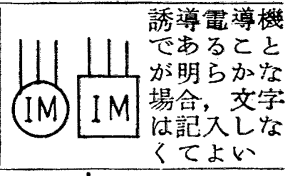 \\
\hline & 直 $\begin{array}{l}\text { 界 } \\
\text { 磞 }\end{array}$ & & $\begin{array}{l}\text { J I Sでは両 } \\
\text { 者を区別しな } \\
\text { ） }\end{array}$ \\
\hline & \begin{tabular}{l|l|} 
年用 & 電 \\
& 機 \\
\end{tabular} & & $\left\{\begin{array}{l}\text { 記号で電動機 } \\
\text { 発電機を区別 } \\
\text { する }\end{array}\right.$ \\
\hline \multicolumn{2}{|c|}{ 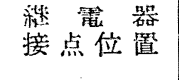 } & & よくに指定しない \\
\hline 抵 & 固 定 & 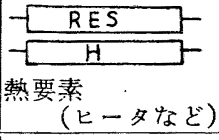 & 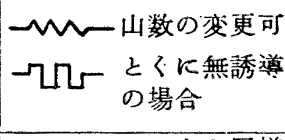 \\
\hline 器 & タップ付 & $-L$ & 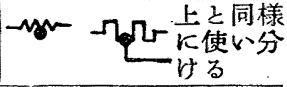 \\
\hline
\end{tabular}


（第 2 表 d)

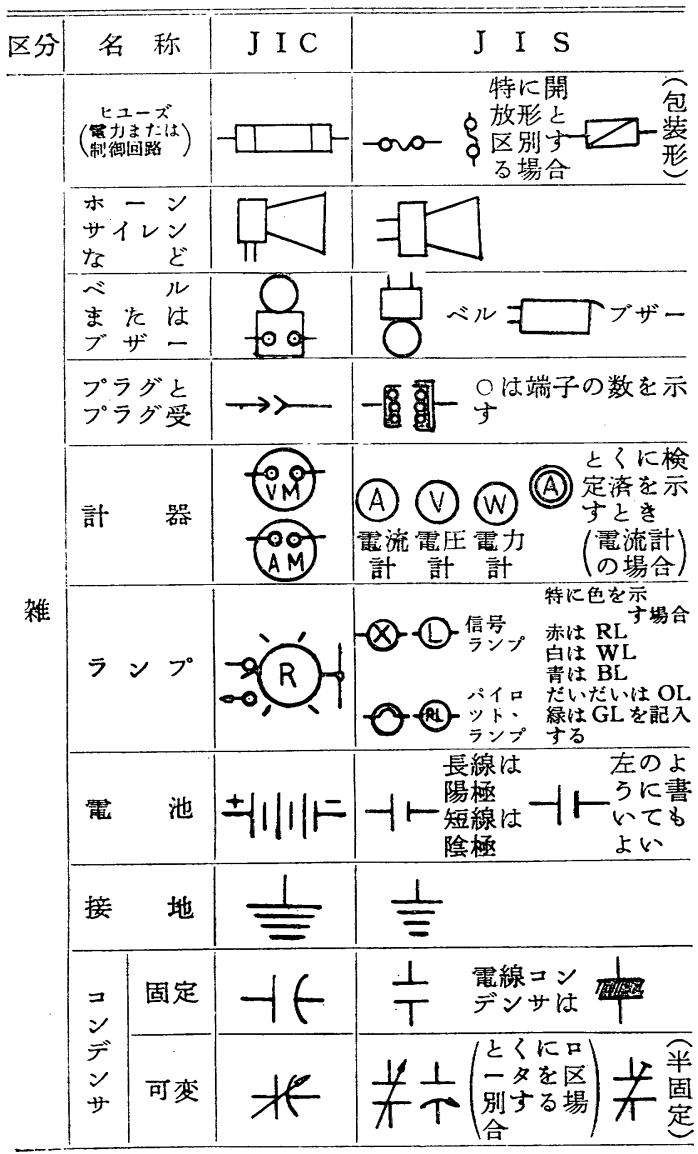

第 2 図は容量の中に被処理物体を入れ, はじめ被処理 物体の外側から処理用気体を入れて時間 $t_{1}$ の間処理し, ついで内側から気体を入れて時間 $t_{2}$ の間処理するとい うバッチプロセスである.

第 3 図はこのシーケンス制御の配線図である。1 番地 （2 番地と連動）の始動ボタンを押すと, 継電器 $A$ と $B$ のコイルに電流が流れ両継電器は動作する. このうち $A$ は自己保持する.すると 18 番地にある接点 $A_{2}$ が閉じる ので弁 $V_{O}$ 用の電磁弁に通電され $V_{O}$ は開となる.すると

× 自己保持とは, 自分の接点を通して自分のコイル に電流が流れ, 他の回路が切れてもその継電器は 動作しつづけるととをいう，第 4 図は自己保持回 路の例である。接点 $A$ が閉じると継震器 $B$ のコイ ルに電流が流れ， 2 番地の接点 $B$ は閉じる。この

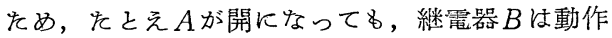
しをます保持される。との自己保持を解くには押 ボタンスイッチを押すか, 接点 $C$ を開にする

$\times \times$ ダイヤフラム弁の上に第 5 図のような小形空気用 雪磁弁を設け，それを介して弁を空気圧で駆動す ると，信頼性が向上する。第 2 図の $V_{0}, V_{I}, V_{O}$ などには大口径（1 in 以上）の直接電磁駆動され る弁を使うよりとの方がよい
（第 3 表） 継電器の表示法の例

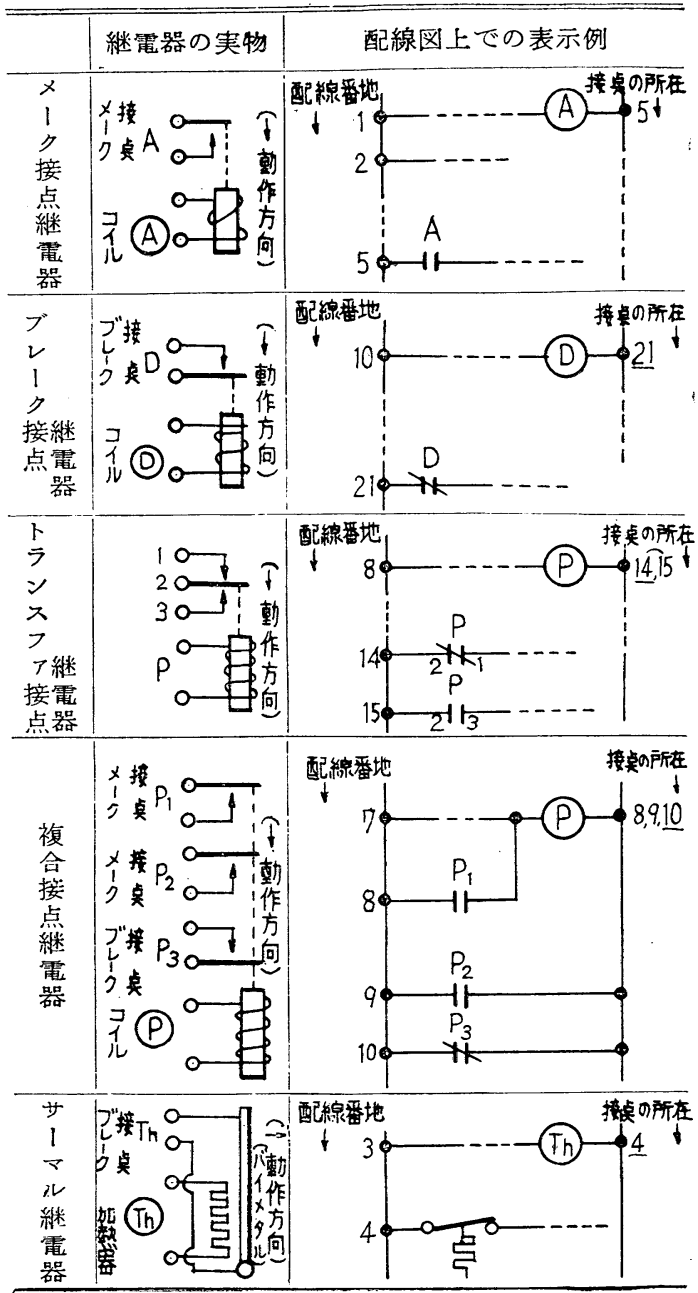

容量内の前の工程での残留気体は $V_{0}$ および $V_{I}$ を介し て $V_{O}$ を通り，外へ排出される．同時に 31,33 番地の $B_{1}, B_{2}$ が動作するので, 工程表示管は 1 を表示する. 容器内の圧力はしだいに下がり, 低玨スイッチ $S W_{L}$ (第 6 図）が閉となり継電器 $C$ が動作し, $D か ゙$ 自己保持する. すると 18 番地の回路が切れ $V_{\sigma}$ は閉じ，また 21 番地の 回路が閉じ三方弁 $V_{0}$ は切りかわり， $V_{0}$ を通して処理 用気体は容器に入る.同時に工程表示管は 2 を表示する. 容器内の圧力が上がって一定值になると高圧スイッチ $S W_{\boldsymbol{H}}$ が動作し, 継電器 $E$ は働き $F$ は自己保持する。 こ のとき $S W_{L}$ は当然開になっていて継電器 $C$ は復帰して いる.また同時に 16 番地の接点 $F_{4}$ が閉となりタイマ $T_{1}$ は始動する. 同時に 36,37 番地の接点 $F_{1}, F_{2}$ が動作し て表示管は 3 を表示する. タイマ $T_{1}$ に設定した処理時 間 $t_{1}$ が経過するとタイマは停止して 8 番地の接点 $T_{1}$ が 


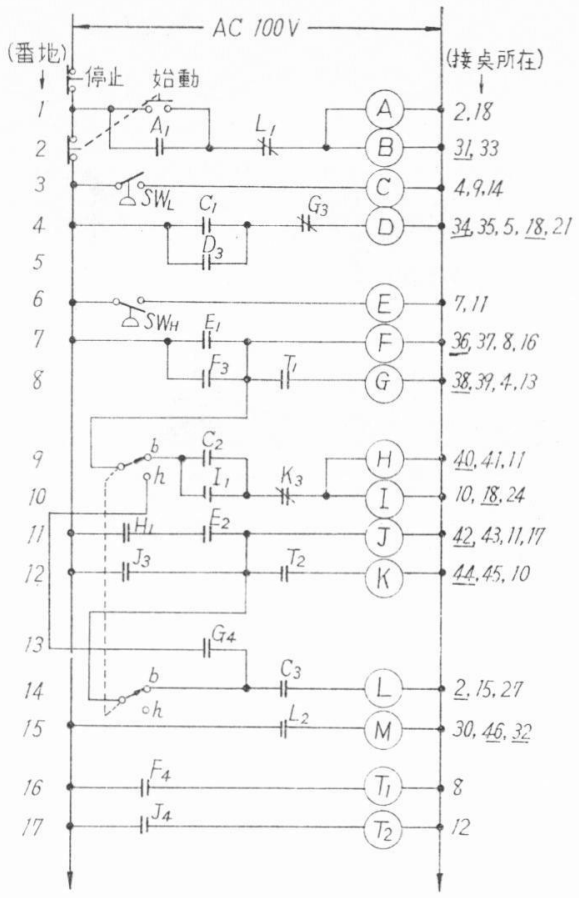

(a)
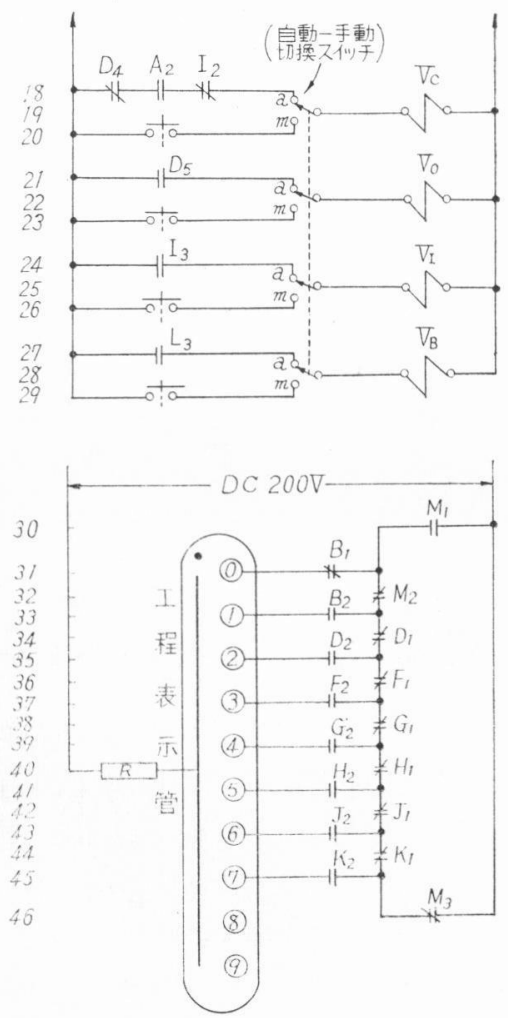

(b)

（第3図）第2図の装置の老めのシーケンス 制御装置配線间

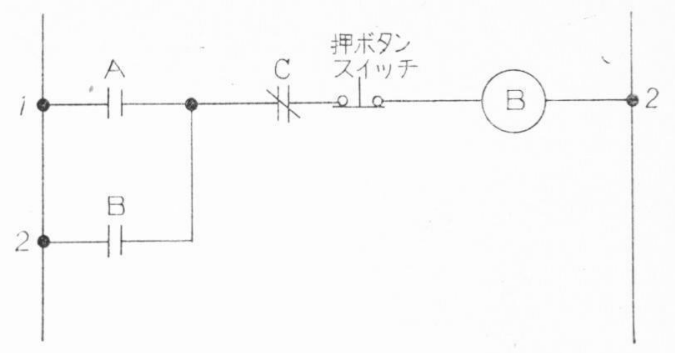

（第 4図）自己保持回路

閉じ, 継電器 $G$ は動作し, 4. 番地の接点 $G_{3}$ が開き, 自己保持していた継電器 Dは復帰する.すると $V_{O}$ は開き $V_{0}$ が切りかわる。 同時に工程表示管は 4 を 表示する。この段階で容 器内の気体は $V_{0}$ または $V_{I}$ と $V_{C}$ を通って外部 へ排出される。

以下順次継電器やタイ マなどの動作を追ってい たたけば,このシーケン ス制御は理解されるはず

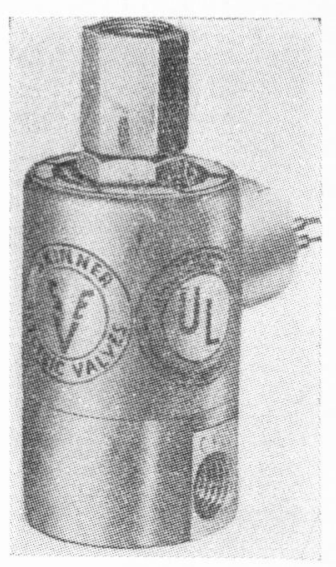

（第5図）安価で信頼性の 高以空気専用小形電磁弁 (スキナ弁)

であるが，上記です

でに感じられたよう

に, シーケンス制御

回路の動作を逐次追 ってゆくことは複雑 かつ単調で, たいて いは途中で面倒にな ってしまう。そこで 実際にはシーケンス チャートという表を 作り，これを一目瞭 然にするのである. 第 4 表第 3 図の回 路のシーケンスチ

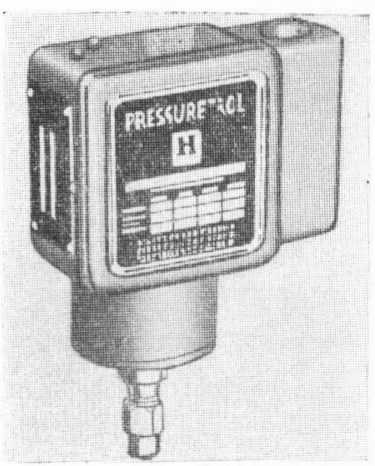
銅製ペローズの伸縮によって 水銀スイッチを開閉させる

（第6図） 圧カスイッチ (山武八ネウェル) ヤートである. 左端の操作番号にしたがって順次この表 を見ていただけば，第 3 図の回路のシーケンス制御動作 はすぺておわかりいたたけけと思う。

第 3 図の9番地と 14 番地にある切換えスイッチをh の側に倒すと，第 4 表で工程は 4 から，一足飛びに 5 ， 6，7を飛び越して 8 に行くよらになる.つまり内側よ 


\begin{tabular}{|c|c|c|c|c|c|c|c|c|c|}
\hline 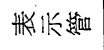 & 0 & $r$ & N & $m$ & F & 10 & 0 & $r$ & 0 \\
\hline$z$ & 紫些 & 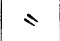 & $\therefore$ & 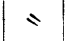 & 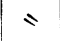 & 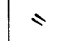 & $s$ & $\therefore$ & 雷䖝 \\
\hline$\rightarrow$ & 刑整 & $s$ & $=$ & $=$ & $s$ & $s$ & 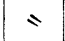 & $\therefore$ & 雷业监 \\
\hline 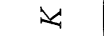 & 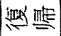 & 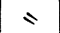 & $\therefore$ & $=$ & $s$ & $s$ & $s$ & 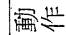 & $=1$ \\
\hline$\rightarrow$ & 想 些 & " & $s$ & " & " & s & 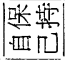 & s & $=$ \\
\hline- & 型些 & $s$ & " & $=$ & s & 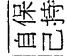 & s & 烈留 & $s$ \\
\hline$I$ & 刑刑韭 & s & $s$ & $s$ & $\therefore$ & 雷业 & $s$ & 秘些 & s \\
\hline 0 & 血些 & $s$ & s & s & 洒 & s & s & $s$ & $s$ \\
\hline I & 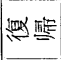 & $=$ & $s$ & 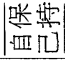 & $s$ & $=$ & s & s & s \\
\hline \& 1 & 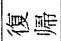 & $=$ & s & 檑 & 瑟㫿 & $=1$ & 盆些 & 些些 & $s$ \\
\hline a & 唄些 & " & 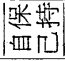 & $s$ & 酊然 & $=$ & " & " & $=$ \\
\hline U & 泪整 & $s$ & 雴 & 然些 & $s$ & 雴造 & 㖞傿 & $s$ & 溧 \\
\hline$\infty$ & 㨽些 & 道蓝 & $\therefore$ & $\therefore$ & s & $s$ & $=$ & s & 紫些 \\
\hline$\nabla$ & 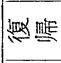 & 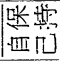 & $s$ & $=$ & $=$ & $s$ & $=$ & $=$ & 紫 \\
\hline$H^{*}$ & 些照 & $s$ & $s$ & $s$ & $s$ & $s$ & 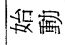 & 些当 & $=$ \\
\hline$E^{-1}$ & 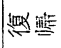 & $s$ & $s$ & 倠窗 & 照 & A $s$ & s & s & s \\
\hline 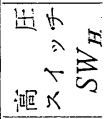 & 㗖 & s & s & 硻 & 䇛 & s & 熙 & 䟼 & s \\
\hline 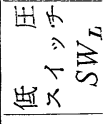 & 㗪 & $s$ & 䛓 & 亚 & s & 监 & 䟧 & $=$ & 器 \\
\hline$\underset{11}{\text { 依 }}$ & 䂑 & $s$ & $=$ & " & " & s & " & s & 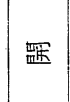 \\
\hline 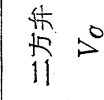 & 涢 & 霘 & 毉 & s & 踇 & 监 & $=$ & 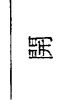 & 監 \\
\hline 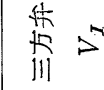 & $\ddots$ & $s$ & $s$ & $s$ & $s$ & $\hat{\jmath}$ & $s$ & $\ddots_{\varphi}$ & $s$ \\
\hline 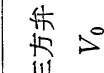 & $\ddots_{,}$ & $s$ & $\vartheta$ & $s$ & $\ddots$ & $=$ & $s$ & s & s \\
\hline 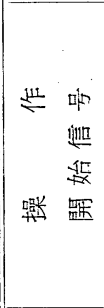 & 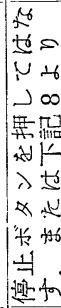 & 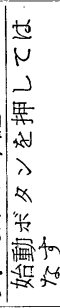 & 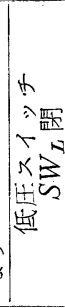 & 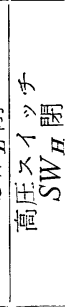 & 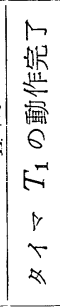 & 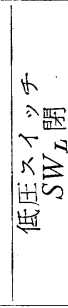 & 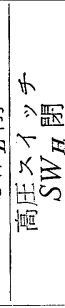 & 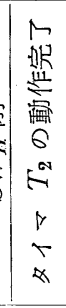 & 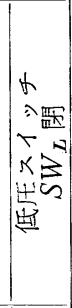 \\
\hline 唪 & 虾 & 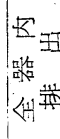 & 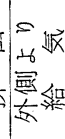 & $\begin{array}{l}r \\
\text { 带 } \\
\text { 这 }\end{array}$ & $\frac{11}{4 ! 3} \cdot$ & 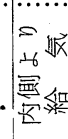 & 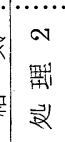 & 王. & $\vec{y}$ \\
\hline 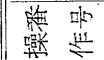 & 0 & $\neg$ & N & $m$ & $F^{\prime}$ & S & 0 & 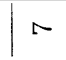 & $\infty$ \\
\hline
\end{tabular}

り給気して時間 $t_{2}$ だけ処理する工程をはぶくようにな る. また 19, 22, 25, 28 の各番地にある切換スイッチは 自動一手動の切換用のものである。 $m$ の側に倒すと手動 となり，20，23，26，29 番地の各押ボタン スイッチによ り手動で各弁を遠隔操作することができるよらになる。 制御装置の故障のときなどに利用できる.

4.4. 着火のシーケンス制御

ボイラをはじめ各種の燃焼装置のバーナの自動着火は 最近かなり実用化されてきている，原理は最初エアパー ジをして爆発を防ぎ，つい゙パイロットバーナに着火 し，それを熖検出リレーで確認して後主バーナに着火す

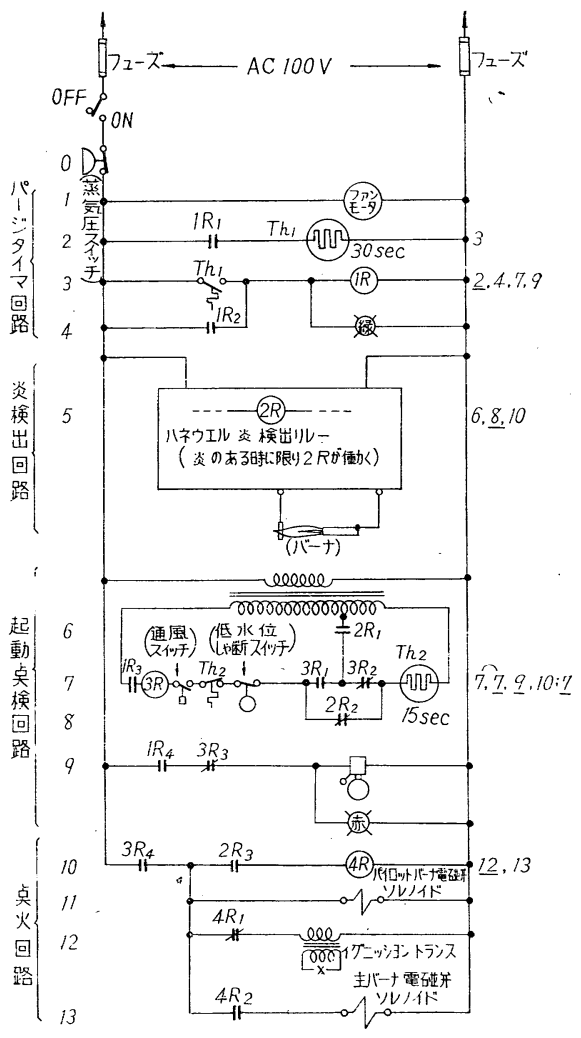

（第 7 図） 自動着火シーケンス制御回路

るといらものである。第 7 図はハネウェル社の開発にな るとのシーケンス制御回路で, 上記正常時に打ける自動 着火のほか，たとえばボイラ気胴内が水不足のとき，エ アパージ不良のとき，着火失敗のときなどに自動的に警 報を出したり, 自動的に再点火を行なうもので, はじめ に述ベた「シーケンス制御」の JIS 原案の用語の意昧 の備考に対するもっとも簡単で適切な例であると思う。 第 5 表はこの動作表である，前例にならって順次見てい ただきたい，とくに自動中止や自動再点火，自動停止と 
（第 5 表）第 7 函の自動着火シーケンス制衔のシーケンス動作表

（）内は所在番地を表わす

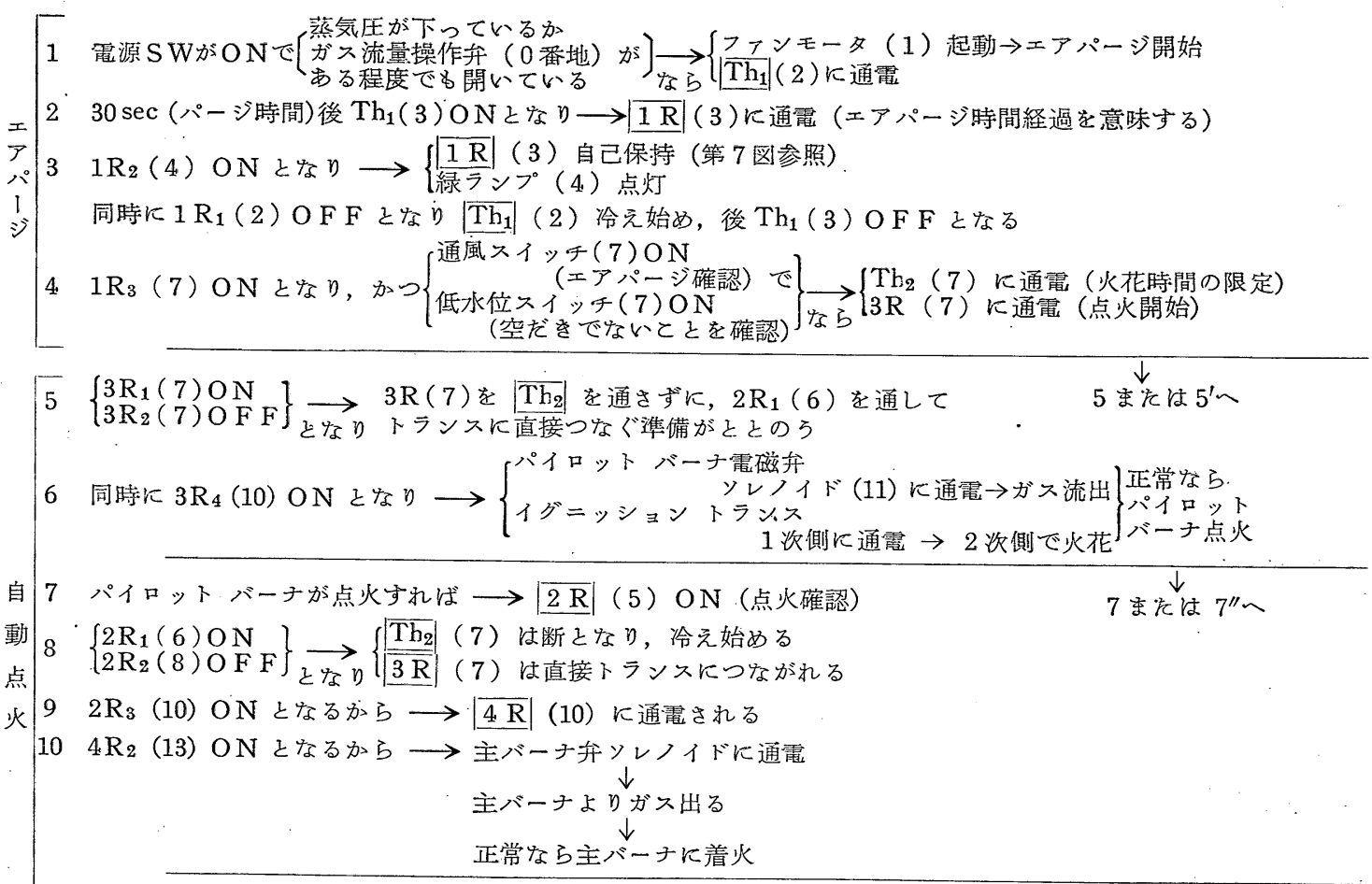

$114 \mathrm{R}_{1}$ (12) O F F で $\longrightarrow$ イグニッション止る

11または $11^{\prime \prime \prime}$

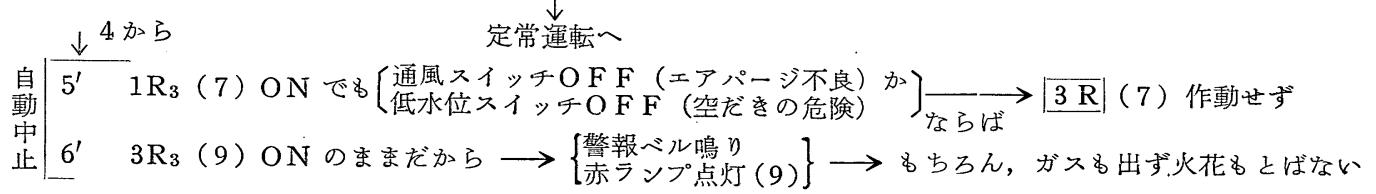

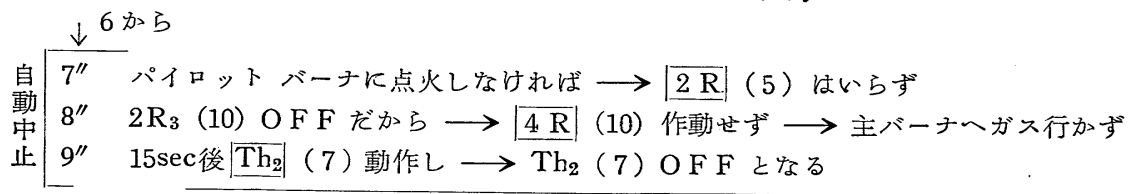

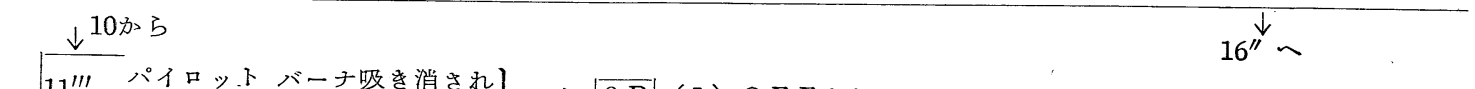

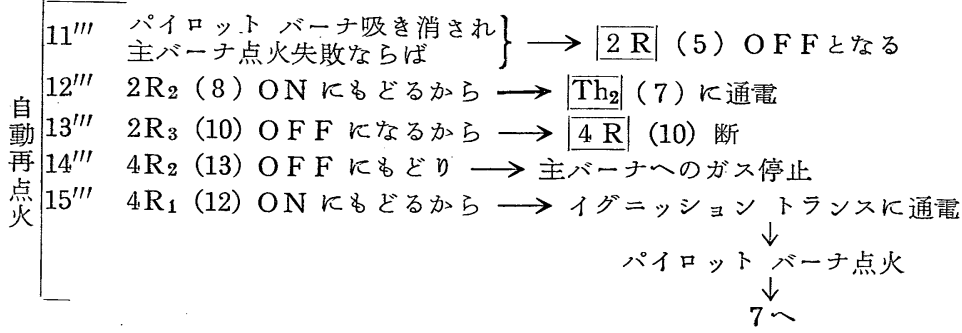

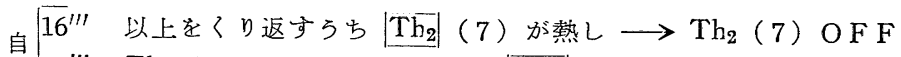

動 $17^{\prime \prime \prime} T h_{2}(7)$ OF F. 犬゙から $\longrightarrow 3 \mathrm{R}$ (7) 断

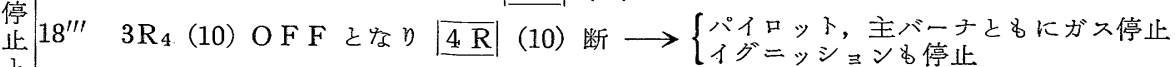

之

警 $19^{\prime \prime \prime} 3 \mathrm{R}_{3}(9) \mathrm{ON}$ となり

（1 R $\mathrm{R}_{4}$ (9) ほ $\overline{1 \mathrm{R}}$ （3）の自己保持により ONになっている） 
警報など巧妙をきわめているものである.

\section{5.おわりに}

以上でシーケンス制御の概要はおわかりいただけたこ とと思う。この解説では継電器式シーケソス制御につい て主として述べたが，周知のと扣り現今は半導体ばやり である、読者の中にはいいまごろ古くさい継電器の話を して何だろう”と思われた方も少なくないであろう.たし かにトランジスタ, シリコン制御整流器, 無接点継電器 など新素子も多く出回ってきてはいるが，継電器にも捨 てがたい長所，とくに一つのコイルに多数の接点を積む ことができ，かつ接点間の抵抗が開のときには無限大で 閉のときには零という長所があり，そのうえ長年月の間 の経験に裏づけられた信頼性がある，最近の継電器には 非常に優秀なものが多い。このため当分の間は継電器式 シーケンス制御装置は現場からは消え去らないことは明 らかである，上記新素子によるシーケンス制御装置は未 だ研究室装置や試作品としての段階のもので, 筆者はま だ責任をもって現場の実用機には拉すすめすることはで きないと思っている。

しかし，汎用シーケンス制御装置の開発とあいるって 次第に上記新素子が導入されることは当然の流れである 5.
最近では最適制御だの適応制御だのと，自動制御界は 討論が活発である。しかし，それらはいっこうに実用化 されてこないそれれはそれらの制御方式には必然性が少 ないからであろう。換言すればそれらは思想から生れた 制御方式であって, 現場の要求からやむなく生まれたも のではないといえよう、だがシーケンス制御は現場の必 然の要求を背景にして, 目下日本の各産業で着々と実施 されその成果をあげている。外国の学術雑誌にシーケン ス制御が載っていたから行なわれるようになったのでは 決してないことを明記したい，諸外国の状態にはdった く無関倸に，日本の工業の特殊事情こそがシーケンス制 御を真に必要としているのである。いますぐに各種瀻維 工業に応用されることを望んで止まない。

\section{文献}

1）森 政弘：“自動化促進に対するシーケンス制御 の役割之効果”，機械学会誌，66，530，p. 360 370 (1963-3)

2）森 政弘：“汎用シーケンス制御装置”，第6 回自 動制御連合講演会前刷, p. 203 204（1963）

3) 原 明弘, 飯田 裕, 山下 直: “シーケンス用 電子計算機の機能に関する考察”，第6 回自動制 御連合講演会前刷, p. 205 260（1963）

4. 森 政弘：“汎用作業順序自動進行装置”, 昭和38 年特許願 60259 号

5）シーケンス追動制御便覽，オーム社 